Historic, archived document

Do not assume content reflects current scientific knowledge, policies, or practices. 



\section{EFFECTS OF FLUE-CURED TOBACCO PROGRAMS ON RETURNS TO LAND AND LABOR}

ECONOMIC RESEARCH SERVICE, U.S. DEPARTMENT OF AGRICULTURE, in cooperation with 
CONTENTS

Page

HIGHLIGHTS $-\ldots-\cdots-\cdots-\cdots-\cdots$

INTRODUCTION $-\ldots-\ldots-\ldots-\ldots-\ldots$

OBJECTIVES AND GENFRAL APPROACH $-\ldots-\ldots-\ldots$

STUDY AREAS - - - - - - - - - - - $-\ldots-\ldots$

ESTIMATES OF LAND AND LABOR RETURNS - - - - - - - - - - - - 3

Sources of Data - - - - - - - - - - - - - - - - - 3

Methods of Estimating Returns - - - - . - - - - - - 4

Results - - - - - - - - - - - - - - - - 5

EFFECTS OF TENURE ARRANGEMENTS ON THE DISTRIBUTION

OF BENEFITS OF FLUE-CURED TOBACCO PROGRAMS $-\ldots$

Sources of Data $-\ldots-\ldots$

Results $\ldots \ldots \ldots \ldots$

EFFECTS OF FLUE-CURED TOBACCO PROGRAMS ON LAND RENT - - - - - - - 13

Some Theoretical and Procedural Considerations - - - - - 13

Results - - - - - - - - - - - - - - - - - 15

Washington, D.C. 20250

June 1968 


\section{HIGHLIGHTS}

This study shows that, in the long run, landowners in the Coastal Plains of North Carolina and the Pledmont area of Virginia, two major flue-cured tobacco production areas, were the principal beneficiaries of Faderal programs to control the price and production of flue-cured tobacco. It was estimated that, in both areas, returns to land increased continuously between the early $1920^{\prime} \mathrm{s}$ (or before the initiation of the flue-cured tobacco programs in 1933) and 1960.

Increases in returns to factors of production attributable to the fluecured tobacco programs cannot be calculated precisely. In this study, benefits from the programs were expressed as influences on variables, such as prices, yields, labor requirements, and costs, affecting income from tobacco production. As a result of the programs, yields and prices of tobacco increased and labor required per pound of tobacco produced decreased. These changes had a positive effect on the increase in income to land per acre; increase in price per pound of tobacco had the largest effect. Increases in labor earnings and overhead and operating costs tended to decrease returns to land. Between the early 1920's and 1960, changes in these variables resulted in an increase in returns to land of $\$ 190$ per acre in North Carolina and $\$ 88$ in Virginia.

Although income to labor also increased during this same period--up 70 cents per hour in North Carolina and 61 cents in Virginia--the increases, in the long run, were not due to the flue-cured tobacco programs. It was estimated that, in the study areas, increases in income to labor were approximately equal to increases in their opportunity returns (or returns to other labor for comparable work).

It appeared that tenure arrangements, although unchanging in their agreements between landowners and laborers, were flexible in relation to the general labor market economy. Thus, the tenure arrangements allowed laborers to recelve incomes equal to their opportunity returns and did not, therefore, appreciably influence the distribution of the benefits of the flue-cured tobacco programs in favor of the laborers. There were evidences that these arrangements were influential for short periods of time, such as a sequence of a few years. However, since the primary interest in the study was in the long-run effect of the tobacco programs, it was concluded that labor returns were what they would have been without these programs. 


\section{EFFECTS OF FLUE-CURED TOBACCO PROGRAMS ON RETURNS TO LAND AND LABOR}

by

J. L. Hedrick, G. S. Tolley, and W. B. Back 1/

\section{INTRODUCTION}

Programs to control production and to support the price of flue-cured tobacco have been in effect for more than 30 years. 2/ There has, however, been 1 imited study of the effects of these programs on income to land and labor. The few studles directly concerned with the effect of these programs on income to factors of production have emphasized how a tobacco allotment affects the sale value of land. Land with a tobacco allotment is estimated to be much more valuable than comparable land without an allotwent. 3/ Some studies have been made of the effects of acreage allotments and price supports on production practices. $4 /$ Previous studies have suggested that income to land has been affected more by the tobacco programs than Incom to labor.

1/ J. L. Hedrick, formerly an agricultural economist with the Economic Research Service of the U. S. Department of Agriculture, is now Senlor

Research Analyst at the Resource Management Corporation. G. S. Tolley, formerly professor of economics at North Carolina State University, is now professor of economics at the Univeraity of Chicago. H. B. Back 1s an agricultural economist in the Natural Resource Economics Division, Economic Research Service, U. S. Department of Agriculture.

2/ For a description of the leglslative history of flue-cured tobacco programs, see Brooks, R. C., and Williamson, J. C., Jr. Flue-Cured Tobacco Program8, 8933-1958. N. C. Agr. Expt. Sta. A. B. Inform. Ser. No. 66, 1958. Although poundage quoens were introduced in 1965, this study applies to the acreage allotment and price-support programs in effect for most of the perlod since 1933.

3/ Maler, F. H., Hedrick, J. L., and Glbson, W. L., Jr. The Sale Value of Flue-Cured Tobacco Allotments. Va. Agr. Bxpt: Sta. Tech. Bul. No. 148, 1960. Mason, J. E. Acreage Allotments and Land Prices. Jour. Land and Pub. Ut1lity Bcon., Vol. 22, pp. 176-181, 1946.

4/ Hartman, L. M., and Tolley, G. S. Effects of Federal Acreage Controls on Cost and Techniques of Producing Flue-Cured Tobacco. N. C. Agr. Brpt. Sta. Tech. Bul. No. 146, 1961. 
This study has the following three objectives:

(1) To measure returns to land and labor used in flue-cured tobacco production for selected periods of time from 1922 to 1960.

(2) To determine to what extent, if any, tenure arrangements affected returns to land and labor and the distribution of benefits of the flue-cured tobacco programs.

(3) To estimate the effects of the flue-cured tobacco programs on the distribution of returns to land and labor.

Accomplishment of the first two objectives is necessary before the inal objective can be realized.

Returns to land and labor are estimated for farms operated under various tenure arrangements in two major flue-cured tobacco production areas--the Pledmont region of Virginia and the Coastal Plains of North Carolina.

Tenure arrangements serve as the institutional means of dividing costs and returns between landowners and tenants (including sharecroppers). Agreements (or contracts) between landowners and tenants in flue-cured tobacco production areas have not changed significantly since 1920. The fact that they have remained unchanged suggests that labor's share of the benefits of the flue-cured tobacco programs is increasing. This would negate the hypothesis that land is the only factor of production receiving increased returns as a result of these programs. An alternative hypothesis is that, in the long run, labor used in flue-cured tobacco production recelves returns approximately equivalent to its opportunity returns (or what it would earn from other comparable work) regardless of tobacco programs or tenure arrangerents. Much of this study is devoted to ascertaining whether, as a result of the tobacco programs, labor has recelved higher returns under vartous cenure arrangements than $1 t$ would have in the absence of the programs.

The opportunity returns to labor are estimated for the study period and compared with estimated earniags of labor in tobacco production. This comparison is made to guage the signifleance of tenure arrangements in the allocation of program benefits. Terms of agreements between landowners and tenants have been characterized as sticky with regard to economic conditions. In this study, tenure arrangements will be considered flexible if they permit labor to recelve actual returns approximately equal to opportunity returns. That 1s, the concept of tenure flexibility adopted for this study is related to the economic forces operating in the labor market.

An estimation of effects of flue-cured tobacco programs on the distribution of Income to land and labor requires the establishment of a quantitative relationship between trends in land and labor. returns and trends in tobacco prices, yields, technological changes, and other dynamic variables, 
such as opportunity returns to 1abor. A procedure was developed for accomplishing this task. 5/ In the procedure, returns attributable to flue-cured tobacco program are expressed as influences on the variables affecting income from flue-cured tobacco production.

\section{STUDI AREAS}

The two reglons selected for this study are the Pledmont of south central Virglnia, where flue-cured tobacco type 11 is produced, and the Coastal Plains of east central North Carolina, where a lighter bodied type 12 tobacco is grown. Historlcally, Elue-cured tobacco production in both regions has been the primary source of farm income. Other important farm enterprises are cotton, peanuts, and corn production in the Cosetal Plains and small grain and livestock production in the Pledmont. Each reglon has share tenuts and sharecroppers, but the multiple cropper unlt farm is more prominent in the Coastal Plains and the share tenant and single cropper unit farm is more characteristle of the Pledmont. 6/ Income from off-farm jobs has not provided an appreciable upplement to farm income in either region.

ESTTMATES OF LAND AND LABOR RETURNS

\section{Sources of Deta}

Farm management surveys were the major source of data for this analysis. Two types of studles were particularly applicable: (1) tobacco enterprise studles, and (2) tobacco farm studies. The enterprise studies provided estimates of costs and returns for an acre of tobacco without regard to share agreements. The tobacco farm studles provided information on share agreements and costs and returns for the whole farm, but did rot indicate costs and returns for the tobacco enterprise only. Data on are agreements were obtafned primar11y from the tobacco farm studies. These data were thell applied to the enterprise budgets. Thls resulted in two sets of estimates of land and labor returns in flue-cured tobacco production: (1) those from enterprise budgets, and (2) those from whole farm budgets.

Data on whole farm and enterprise budgets were obtained from 13 studies and many supplementary sources. Estlmates of land and labor returns were obtalned for 1922, 1936, 1949, and 1960 for the Pledmont area and for 192528, 1934, 1947-49, and 1960 for the Casstal Plains area. Data from enterprise budgets were avallable for each of these elght study perlods, but data from whole farm budgets were avallable for only five of the periods-three for Virginia and two for North Carolina.

$5 /$ For details of this procedure, see Hedrick, James Lupton, Measurement and Bxplanation of Factor Returns Under the Flue-Cured Tobacco Program. Ph.D. Thesis, N.C. State University at Raleigh, 1967.

6/ Multiple cropper units are operated by two or more croppers; single cropper units are operated by one cropper. 
The following expresslons represent the procedure used to compute returns to land and labor under crop share arrangements in flue-cured tobacco production:
(1) $R=\frac{j p q-j c_{1}-c_{2}-v}{2}$
(2) $L=\frac{(1-j) p-(1-j) c_{1}-c_{3}+v}{h}$

where:

$$
\begin{aligned}
& \mathbf{R}=\text { Return per acre to landowner } \\
& \text { L - Labor earnings per hour } \quad c_{2}=\text { Landlord costs } \\
& P=\text { Price of tobacco } \\
& \text { a Quant1ty of fobacco produced } \\
& \mathrm{J} \text { - Nomina } \text { ohare to landlord a = Acres of tobacco } \\
& (1-f) \text { Nominal share to tenant or cropper } \\
& c_{1}=\text { Shared costs } \\
& c_{3}=\text { Tenant or cropper costs } \\
& v \text { - Value of perquisites If } \\
& \mathrm{h}=\text { Hours of labor. }
\end{aligned}
$$

In equation (1), Incone per acre to land 18 expressed as the share of gross income recelved by the landowner, $1 \mathrm{ess}$ his costs, which include the value of perquisites provided the cropper. Similarly, in equation (2), Income to labor is expressed s the share of the gross recelpts recelved by the cropper, 1 ess his costs and plus the velue of perquisites provided by the landowners.

These equations do not 180 late managerial returns to landowners or tenants. The landowner typically performs the managerlal service on a cropper farm, 80 his net return includes shares to both land and management. The tenant usually perform the magerinl service on the farm he operates, and his net returns include shares to both labor and management. Thus, returns to mangement may be estimated from elther (1) the difference between landowner returns on cropper farms and landowner returns on tenant-operated farms, or (2) the difference between net returns to croppers and tenants. The second procedure assums the facome to the cropper is a return to labor only. Possible exceptions to this assumption are discussed later to the report.

If Pergisialtes represent the overhend cost to the landlord for the house, garden, pasture, and firewood which the landlord typlcally provides without chrse to the cropper or tenant. These costs include both cash outlays and opportunity returns that could be earned in the absence of a cropper arrangement. The perqulsites are returns to the cropper since the cropper would have to otherwise pay for these provisions. 
Estimates of income to land and labor eso summartzed in tables 1 and 2. Income to management, presented in table 3, 18 the difference between Income to landowners lessing to tensnts and to those leasing to croppers. When estimated from both enterprise and whole farm budgets, returns to land and labor In North Carolins continued to increase throughout all the perlods selected for study. The same was true of returus to land and labor in Virginds when estimated from enterprise budgets. For both tenant and cropper farms in North Carolina and for cropper farms in Virginis, percentage incresses In land income great $1 y$ exceeded those in income to other factors of production. Thus, when considering increases in income to laborers and landlords, the landlords generally fired beter.

The Indication in table 3 that management has a greater value in southern Virginia than in North Carolina is subject to question since tobacco yields and prices are lower in Virginla. The questionable results in table 3 suggest that tenure arrangements in these two tobacco growing areas cannot be considered comparable when estimating returns to management.

As pointed out above, estimates reveal that, since 1920, Income to landomners increased much faster than that to labor in both areas. A basic reason for this is that before the tobacco programs were introduced costs to landowners were about as large as gross returns to them, making the returin to land not much above zero. However, after the programs were initiated, their gross returns rose at a greater rate than their costs, causing a dramatic rate of increase in net returns to land. Simultaneously, since the cash expenses for production are a much smaller proportion of gross returns to the tensnt than of the returns to the landowner, changes in the ratio of production costs to returns affected labor income less. Also, an increase in yields 10 the perlods studled Increased the labor requirements per acre, and this restrained the rate of Increase in income per hour of labor.

The data from enterprise and farm budgets used in this sidy were not obtained In such way as to provide estlmates of variances or standard errors. In the absence of such astimates, a sensitivity analysis was made to ascertain how given percentage changes in gross returns, overhead costs, and operating costs would affect the estimates of land and labor returns. The specific percentages of change used in the amalysis were assumed to be 10 percent for overhead cost and value of perquisite; 5 percent for gross returns, cost of worlistock, and operating costs; and 2.5 percent for hours of labor required. $8 /$ A sumery of the results of this analys 1818 presented in figure 1.

8/ These percentages were estimated as the standard errors tn the enterprise and farm budget data used in this study. The estimates of standard error were based primarily on calculations from data in the budgets for Virginta In the studies made during the $1920^{\prime}$ s and $1930^{\prime}$ and were generally consistent with those estimated from recent and unpublished data collected by the North Carolina Agricultural Experiment Station. 

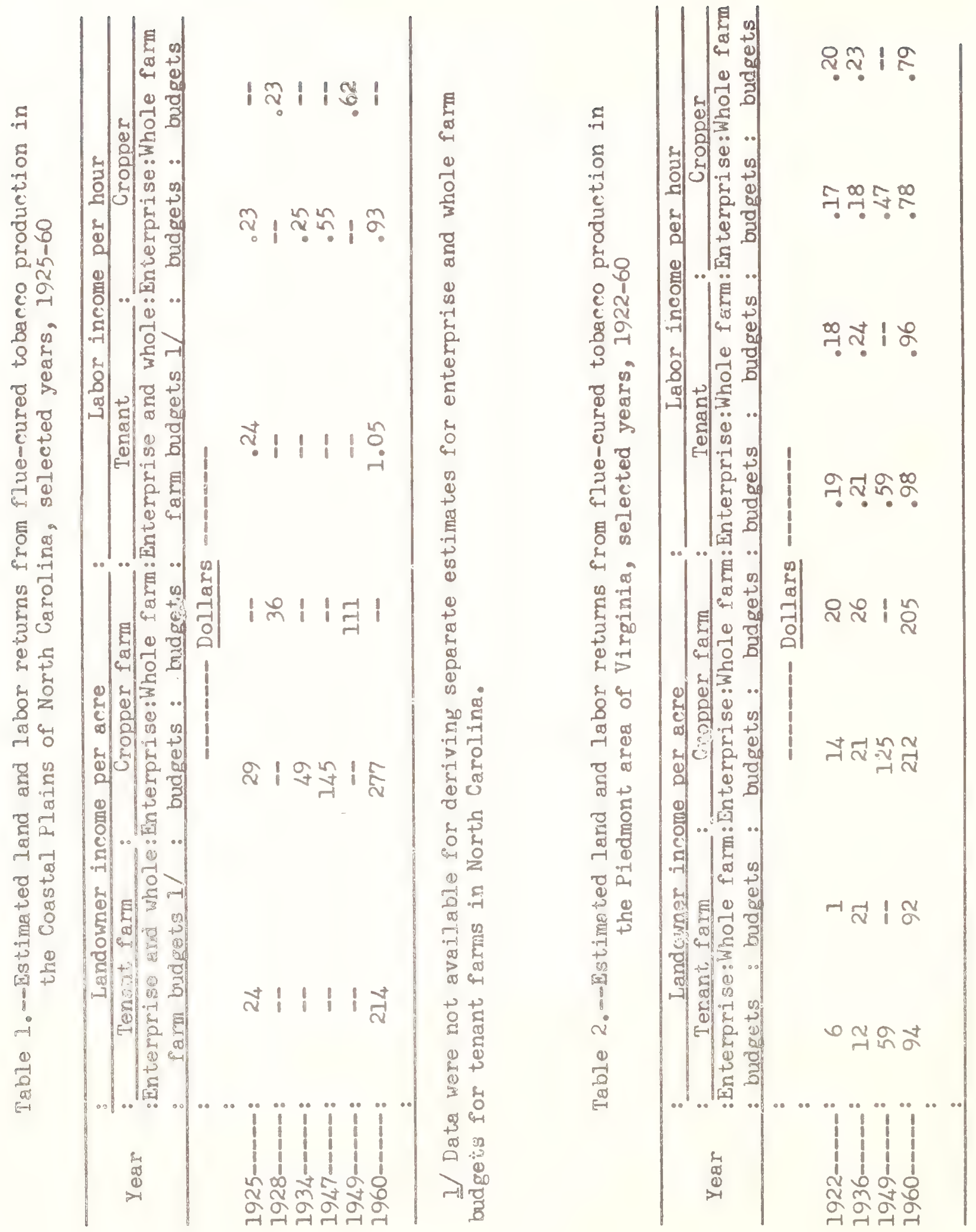
Table 3.--Rstimated management returno per acre from Elue-cured tobacco production in the Coastal Plains of North Carolina and the Pledmont area of VIrginta, selected years, 1922-60

\begin{tabular}{|c|c|c|c|c|c|c|c|}
\hline \multirow{2}{*}{ Year } & $:$ & \multicolumn{4}{|c|}{ Enterpr lse budgets } & \multirow{2}{*}{$\begin{array}{l}: \\
: \\
: \\
:\end{array}$} & $\begin{array}{c}\text { Whole farw } \\
\text { budgets }\end{array}$ \\
\hline & $:$ & North & Carolina & : & Virglnia & & Virglnia \\
\hline & : & \multicolumn{6}{|c|}{$\ldots-D 011$ ars $\cdots \cdots-$} \\
\hline $1922 \ldots \ldots \ldots$ & $-:$ & \multicolumn{3}{|c|}{--} & \multicolumn{2}{|c|}{8} & 19 \\
\hline $1925 \cdots--\infty \ldots$ & & & 5 & & \multicolumn{2}{|l|}{$-\infty$} & $\infty$ \\
\hline $1934 \ldots \ldots-\infty \ldots$ & & $1 / 1$ & 11 & & \multicolumn{2}{|l|}{$-\infty$} & -- \\
\hline $1936-\infty-\infty-\infty$ & & & -- & & \multicolumn{2}{|l|}{9} & 5 \\
\hline $1947---0-\infty-\infty-$ & & $\underline{1 / 3}$ & 36 & & \multicolumn{2}{|l|}{$-\infty$} & -- \\
\hline $1949=-\cdots-\cdots-\cdots$ & & & -- & & \multicolumn{2}{|l|}{66} & -- \\
\hline $1960 \cdots \ldots \ldots$ & & & 63 & & \multicolumn{2}{|l|}{118} & 113 \\
\hline
\end{tabular}

1/ Estimates of management returns for 1934 and 1947 in North Carolina were based on the conventionsl arrangement of one-third of returns to landowner and two-thlrds of returns to tenants. Data were not avallable for deriving detalled budgets for tenat farms in these yesrs for North Carolina.

Thls andysis revealed that the return to land is much more affected by changes in gross returns or costs than is the return to labor. Income to land in Virginia was found to be more affected by these changes than was income to land in North Carolina. Land returns become less sensttive to changes in gross returns and costs as they increase; labor returns show practically no sensitivity to these changes.

\section{BEFECTS OF TRNURE ARRANGRMENTS ON THE DISTRIBUTION OF BENEFITS OF FLUE-CURED TOBACCO PROGRAMS}

The major purpose of this section is to ascertain whether the almost complece lack of change in the provisions of the share contracts between landowners and croppers or tenants over time has allcwed labor to recefve, as a result of the flue-cured tobacco programs, returns in excess of 1 ts opportunity returns. Whether the effect of tenure arrangements on the distribution of program benefits is neutral, favorable to the sharecroppers or tenants, or favorable to landowners depends on the results of a comparison of (1) actual income of tenants or sharecroppers with their alternative earnings, and (2) labor supplied by tenants and sharecroppers with total labor used in flue-cured tobacco production.

Tenure arrangements which have a neutral effect on the distribution of tobacco program benefits can be considered flexible according to the concept of flexiblifty adopted for thls study. Tenure arrangements are flexible if there 18 no signiflcant difference between trends in cropper returns and trends in their opportunity returus, and between the proportion 


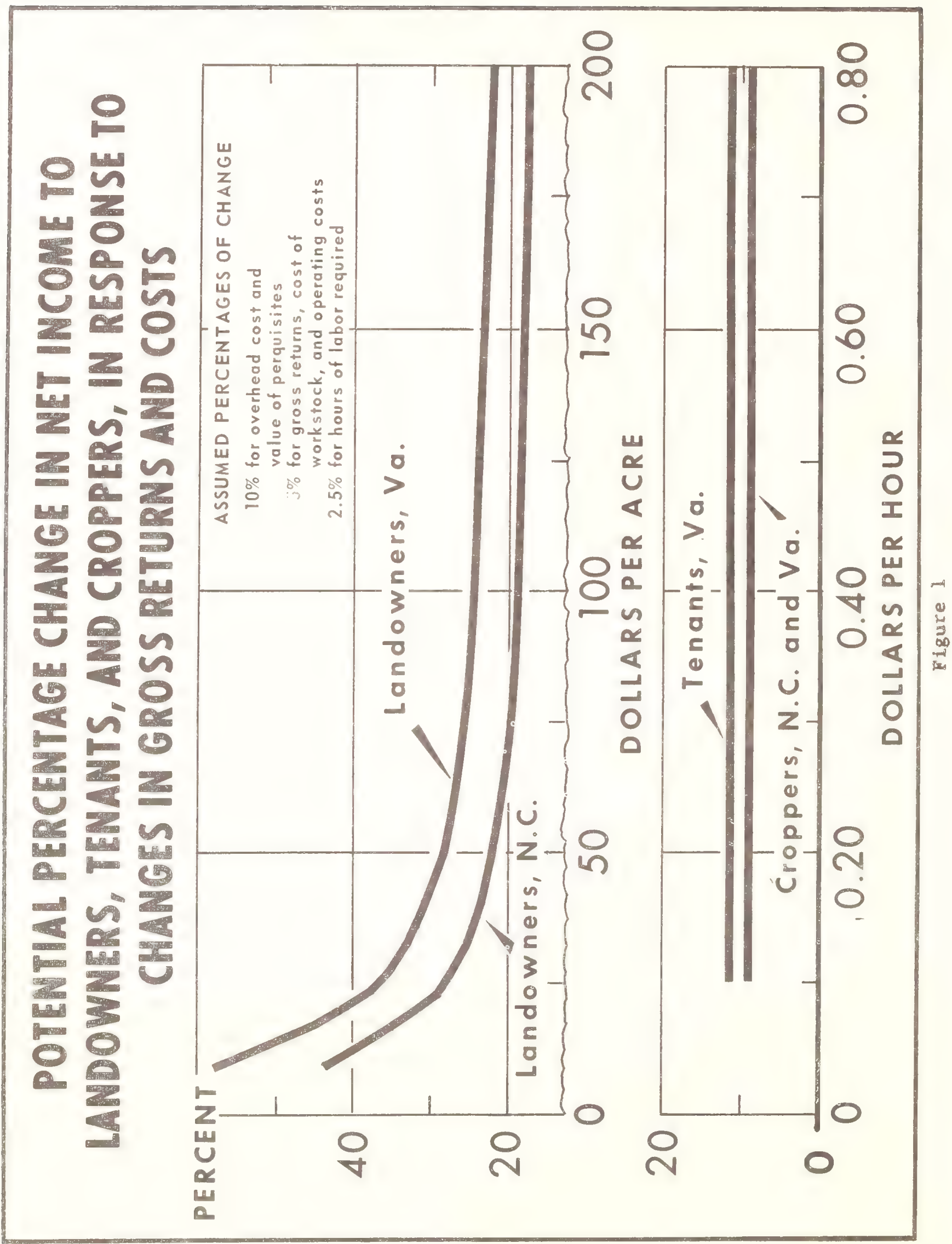


of labor provided by tenants or sharecroppers and that provided by other tenure groups in flue-cured tobacco production, with or without the programs Although tenure arrangements may not be flexible during shoze periods of time, they may be flexible and neutral for a long period of time-ruch as the period since the lnitiation of the tobacco programs. The long period is of primary interest in this study. If tenure arrangements are not neutral or flexible in the long run, it would have to be determined whether they favored the laborers or the landowners in the distribution. of benefits of flue-cured tobacco programs.

\section{Sources of Data}

Opportunity returns--The avallable data prescribe some limits on testing the hypothesis that in their effect on returns to labor tenure arrangements are flexible (or neutral), especially in the long run. The estimated returns to croppers, rather than returns to tenants, are compared with alternative earnings to exclude management returns. The opportunity returns most desirable for comparison purposes are those to labor whose level of skill is the same as that of croppers. In general, croppers are practically unskilled and have little education. Jobs open to these people usually are limited to those as farm wageworkers or unskilled laborers in the nonfarm economy. Ideally, farl wage rates, excluding returns to croppers for the time span of this study, particularly in the two study regions, would provide a relevant set of opportunity returns. Another set would be time series estimates of income to unskilled laborers in urban locations to which croppers typically have Bigrated when shifting to nonfarm employment. Unfortunately, some substitutes for these ideal data are necessary.

Croppers returns were compared with farm wage rates in the study regions as estimated by the North Carolina and Virginia State Departments of Agriculture and Crop Reporting Services for 1922 through 1962. A shortcoming of these data is that the wage of the hired farmworker, as well as cropper returns, may te affected by the flue-cured tobacco programs. Income data from the U. S. Census of Population are avallable for 1940, 1950, and 1960 only. Returns to croppers were also compared with the median income of males classified in the population censuses as laborers, except those in farming and mining. Natlonal wage rates for workers in manufacturIng, as estimated by the U. S. Department of Labor, were used as a third comparison. These rates are also avallable for 1922 through 1962 , but are reported by Industries and areas only since 1950.

Tenure structure--The U. S. Census of Agriculture provides data, by counties, on the number of owner-operators, part owners, tenants, and sharecroppers for 5-year intervals since 1920. Data on the number of hired farmworkers are available by counties beginning with the 1949 Census of Agriculture. Only since the census of 1954 bave data on the number of regular hired workers (those working on farms 150 days or more each year) been available on a county basis. Regular, rather than seasonal work, is the more comparable alternative employment avallable to croppers in the farm economy. 
Opportunity returns--In the Coastal Plains of North Carolina, returns to croppers per hour exceeded farm wage rates in nearly all the 3-year periods between 1922 and 1962 (figure 2). The differences between the hourly rates to croppers and to other farm wage earners tended to widen over time, particularly after 1945. In the Pledmont area returns to croppers per hour and farm wage rates did not appear to differ significantly, particularly after 1930. The difference between the results for North Carolina and Virginia was due to the fact that in North Carolina returns to croppers were higher and farm wage rates were lower than those in Virginia for all of the periods for which comparisons were made.

The higher income to croppers in North Carolina may have been due to the fact that croppers in North Carolina had a higher level of sk111. The multiple cropper unit system, prevalent in North Carolina, may have contributed to a high rate of migration to urban areas by croppers whose level of skill was lower than average. It is easier for landowners of multiple cropper units to reduce the number of croppers in order to adjust to the labor supply than it is for landowners of single cropper units. Also, under the multiple cropper system, it is possible that landowners provided less management to the operations of Individual croppers than they did to croppers operating under the single cropper system. If so, some of the returns to croppers in North Carolina would be returns to management.

Apparently the farm labor markets in the two States differ significantly in composition of the labor force, types of jobs done, and forces affecting wage levels. Farm wage rates in Virginla could be affected more by the urban development in the East than those in North Carolina. Also, average wage rates in North Carolina are affected more by low wage migrant workers harvesting cotton and tobacco than average wage rates in Virginia.

The ratios of returns to croppers in North Carolina and Virginia to wages of workers in manufacturing in the United States are presented in figure 3. Except for the low ratios during 1928-33 for both States, there were no large changes in the ratios between the 3-year perlods from 1922 to 1962 for elther State. Also, the ratios for both States exhibited no overall trend upward or downward during the 40-year period. These results are consistent with the hypothesis that tenure arrangement's are flexible in the long run.

Whether the wages of workers in manufacturing are relevant opportunity returns to croppers in North Carolina or Virginia may be open to some question. However, trends in the wages of workers in manufacturing in the United States reflect economic forces affecting wages generally, particularly those forces establishing the level of nonfarm wage rates.

The ratio of cropper returns to the median income of males in major urban locations from 1940 through 1960 also supports the hypothesis that tenure arrangements are flexible in the long run. For example, the ratio of returns to croppers in both Virginia and North Carolina to the median income of males in Washington, D.C., and New York City was almost the same 


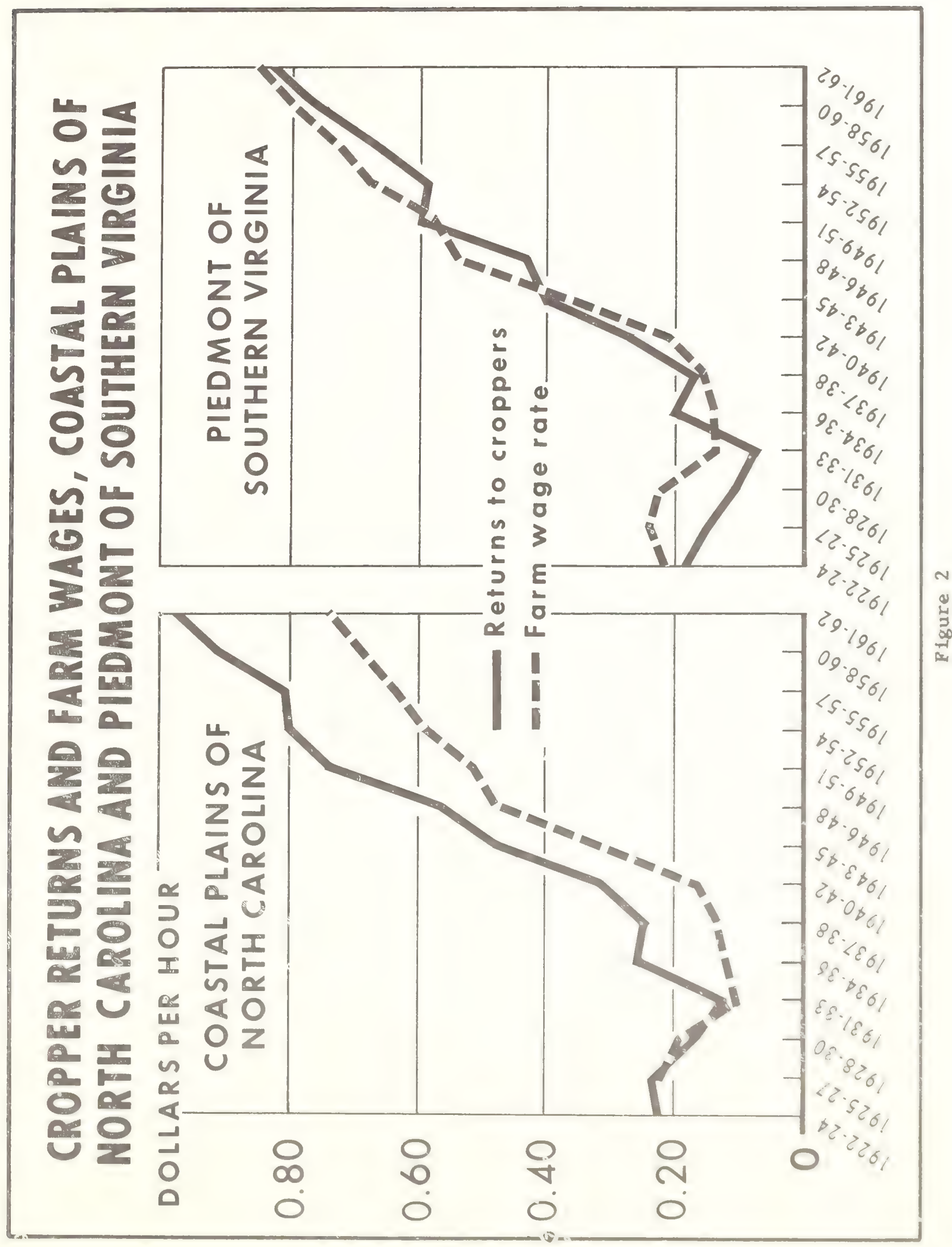




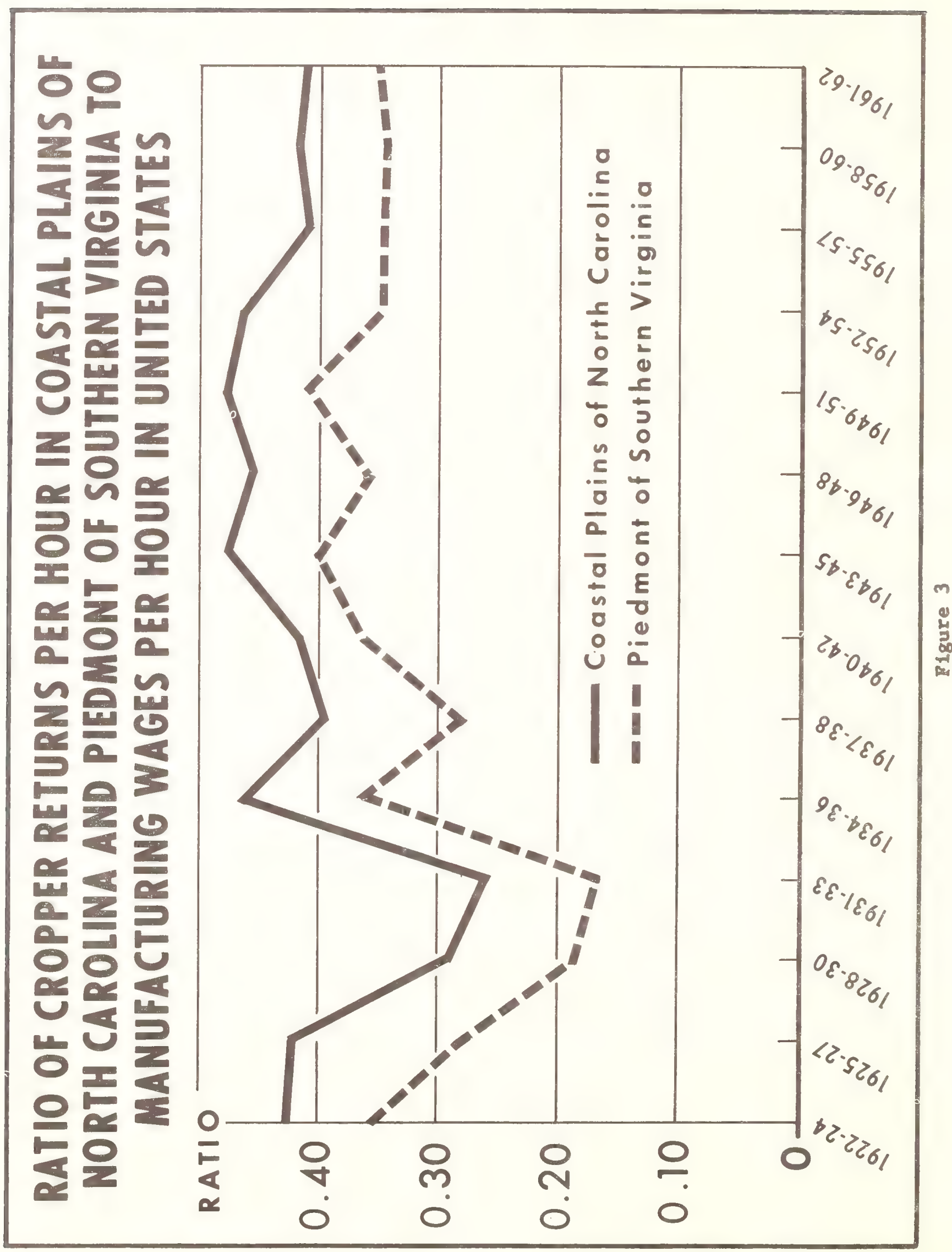


in 1950 and 1960. Washington, D.C, and New York City are major recelvers of migrants from the rural South, particularly negro migrants. In 1940, the returns to croppers in Virginia were 62 percent of the median income of all males classed as laborers, except those in farming and mining; this percentage increased to nearly 74 in 1950, but dropped to about 67 in 1960. On the other hand, the ratio of returns to croppers in North Carolina to the median income of all laborers was nearly constant from 1940 through 1960. The ratios for 1940,1950 , and 1960 were $1.02,1.02$ and 1.05 , respectively.

Tenure structure --From 1925 to 1959, the total number of farms declined by 36 percent in Virginia and 26 percent in North Carolina. Cropper units in this period declined by 33 percent in Virginia and 48 percent in North Carolina. Also, from 1954 to 1959, flue-cured tobacco acreage was reduced by the program by about one-third in both North Carolina and Virginia.

The fact that in North Carolina the number of cropper units declined more than the total number of farms suggests the possibility of a significant shift from cropper to other kinds of labor because of the inflexibility of tenure arrangements. The increasing difference in trends in returns to croppers and in farm wage rates in North Carolina would tend to encourage a substitution of hired labor for cropper labor. However, in relation to the total number of farms in North Carolina from 1925 to 1954, the number of cropper farms changed little. The lack of a trend in this relationship is consistent with the hypothesis that tenure arrangements are flexible in the long run. The multiple cropper unit system in North Carolina provided landowners with more freedom in reorganizing thelr farms into fewer cropper units following the reduction in tobacco acreage than did the single cropper system in Virginia. Thus, it is largely because of the flexibility of the tenure system in North Carolina that the number of croppers decreased considerably after 1954.

Overall, it appears that in the long run (a period of nearly 40 years) the rigid tenure agreements between landowners and tenants have had littlc, if any, effect on the distribution of the benefits of flue-cured tobacco programs. However, avallable data indicate that in both States there have been many instances when these arrangements could have offected the distribution of benefits for short periods of time. Since this study is concerned primarily with the distribution of program benefits for a long period of time, the analysis to follow will be based on the premise that income to labor from 1933 through 1960 did not differ significantly from what it would have been in the absence of the programs. Thus, the problem now is to estimate the effects of these programs on income to land.

\section{EFFECTS OF FLUE-CURED TOBACCO PROGRAMS ON LAND RENT}

\section{Some Theoretical and Procedural Considerations}

Land rent, or income, can be increased by the programs in a number of ways. First, through the pederal price-support and supply control program. 
prices of tobacco are malntained above equilibrium levels over $t$ ime. Second, the acreage control and price-support features of the programs provide producers with an incentive to increase output through increasing ylelds, or through the substitution of nonland inputs for land inputs. The supported price above equilibrium levels makes it profitable to use more units of labor, fertilizer, and other capital inputs than would be used if tobacco prices were lower. Research in new technology, such as Improved varleties, fert1Iizers, or insecticides, also can be, at least partially, related to the producers ' interest in Increasing output per acre under program conditions.

Labor input per acre or per pound of tobacco produced is affected by the programs through both the profltabllity of more intense use of labor and new technology.

To quantify the influence of these variables--prices, yields, labor requirements, and costs--on the returns to land the following equation was used:

$$
\text { (1) } R+y(p-w 1-k)
$$

where:

$$
\begin{aligned}
& R=\text { Returns to land (or rent) per acre } \\
& y=\text { Yleld per acre } \\
& p=\text { Price per pound } \\
& w=\text { Returns to labor per hour (Including management) } \\
& 1=\text { Amount of labor used per pound of tobacco produced } \\
& k=\text { Other costs per pound of tobacco produced. }
\end{aligned}
$$

The costs per pound of tobacco produced include capital outlays by both the landowners and tenants. These capital outlays include expenditures for matenance and operation, or the overhead and operating costs. The portion of the above equation in parentheses equals the returns to land (or rent) per pound of tobecco, or

$$
\text { (2) } r=p-w 1-k \text {. }
$$

Equation (1) can be differentlated to Identify the components of changes in income and costs affecting change in land rent between any two points in time. This procedure results in the following equation:

$$
\text { (3) } \begin{aligned}
\Delta R= & {[r \Delta y]+[y \Delta p]-[y] \Delta w]-[y w \Delta 1]-[y \Delta k]-} \\
& {[y \Delta w \Delta 1]+[\Delta y \Delta r] }
\end{aligned}
$$

where the variables without deltas are as defined above, but apply to a base year (such 28 1922), and the deltas indicate changes in these variables over 
a period of years (such as 1922-1960). 9/ The first five terms in the equation identify the independent effects of each of the variables affecting rent. These independent effects are obtained by holding all variables constant at the base year levels except the one under consideration. Since all the variables change over the period of the study, their interaction produces additional effects on the change in land rent per acre. The last two terms of the equation express these interaction effects.

In this study, the base year is 1922 for V1rginia and 1925 for North Carolina and the ending year for both States is 1960. Since changes in rent must exclude returns to management, the budgets for the base years and ending year used to estimate the components of change in rent per acre were for the tenant-operated farms.

\section{$\underline{\text { Results }}$}

Data from the tenant enterprise budgets used for deriving values for the variables in equation (3) are presented in tables 4 and 5. 10/ All changes in the variables in both States were positive except those in hours of labor used per pound of tobacco produced. The hours of labor decreased because of labor-saving technologies applicable to preharvest operations, and because labor required per pound of tobacco in producing and marketing operations decreases with increases in yields per acre. In both States, ylelds, prices of tobacco, and overhead and operating costs more than doubled during the study period.

In table 6 , the components of changes in income and costs affecting land rent add up to the actual changes in the returns to land which were indicated earlier in tables 1 and 2 on tenant-operated farms. In both States, the component increasing rent the most was the increase in price per pound of tobacco, and the largest deterrent to the increase in rent was the increase in returns per hour of labor. The effect of the increases in price of tobacco, which includes a component due to the programs, was much higher than the $\$ 271$ and $\$ 230$ shown as independent components for North Carolina and Virginia, respectively. Consequently, the negative components of change in rent per pound (returns to labor per hour and other costs per hour) were overbalanced, causing the interaction of changes in yield and in rent per pound $(+[\Delta y \Delta r])$ to have positive effects. Similarly, the negative, independent (nonprogram) effects of Increased returns per hour of labor was more than that presented in table 6; thus, the magnitude of the positive effects of both interaction components $([\Delta w \Delta 1 y]$ and $[\Delta y \Delta r])$ was reduced. The direct effect of increasing ylelds upon rent per acre is the result of its independent component and the interaction of increases in yleld and rent per pound of tobacco. However, there are indirect positive effects of yield increases. such as influences upon labor required per pound of tobacco and upon the

$9 /$ The expressions $r$ and $\Delta r$ (rent and change in rent per pound of tobaceo) are put in the equation instead of $(p-w 1-k)$ and $(\Delta p-1\rfloor w-w\lrcorner 1-\lrcorner 1\lrcorner w-\perp k)$.

$10 /$ Coples of all budgets used in this study may be obtained, upon request, from the Natural Resource Economics Division, Economic Research Service. U.S. Department of Agriculture. 


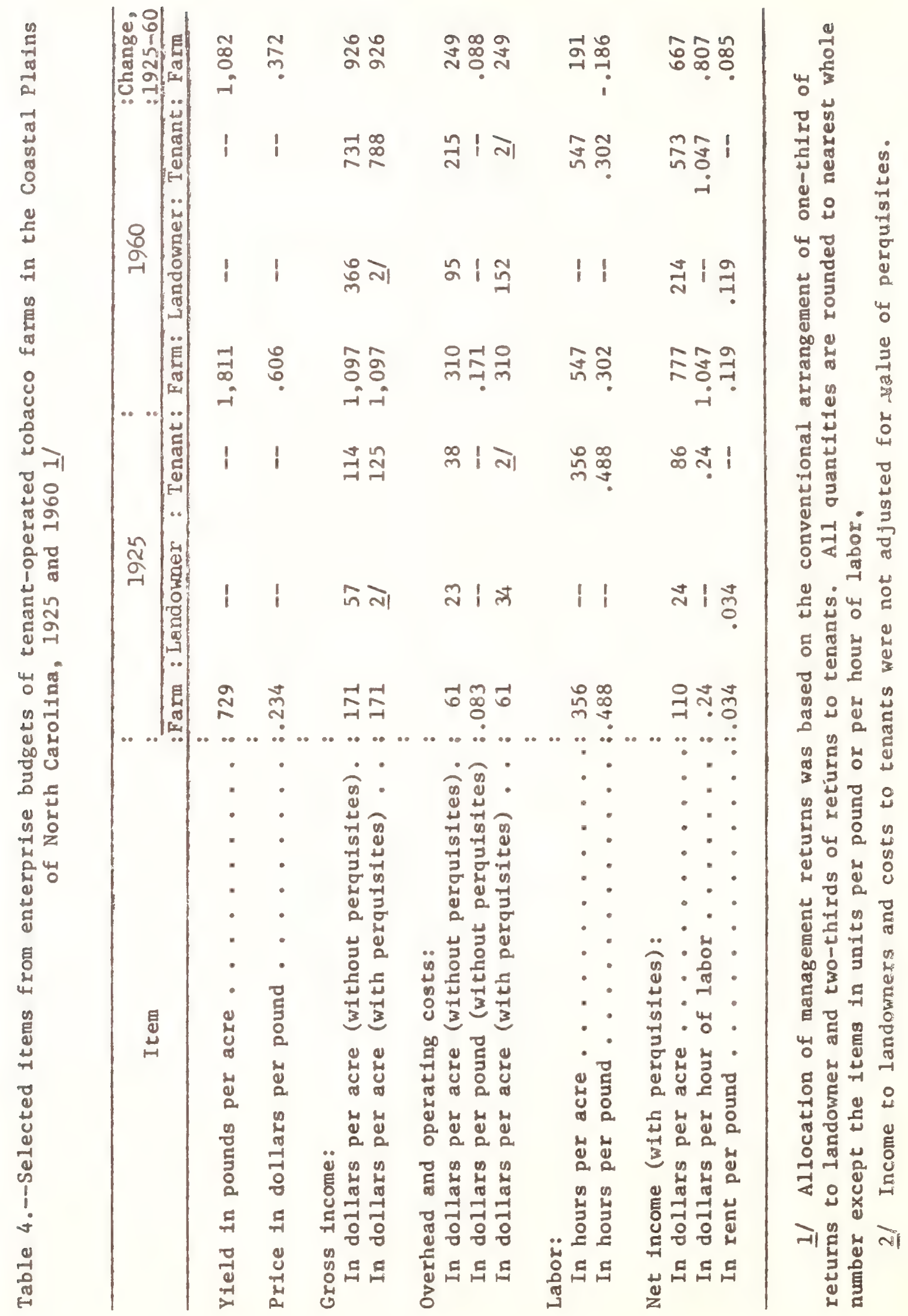




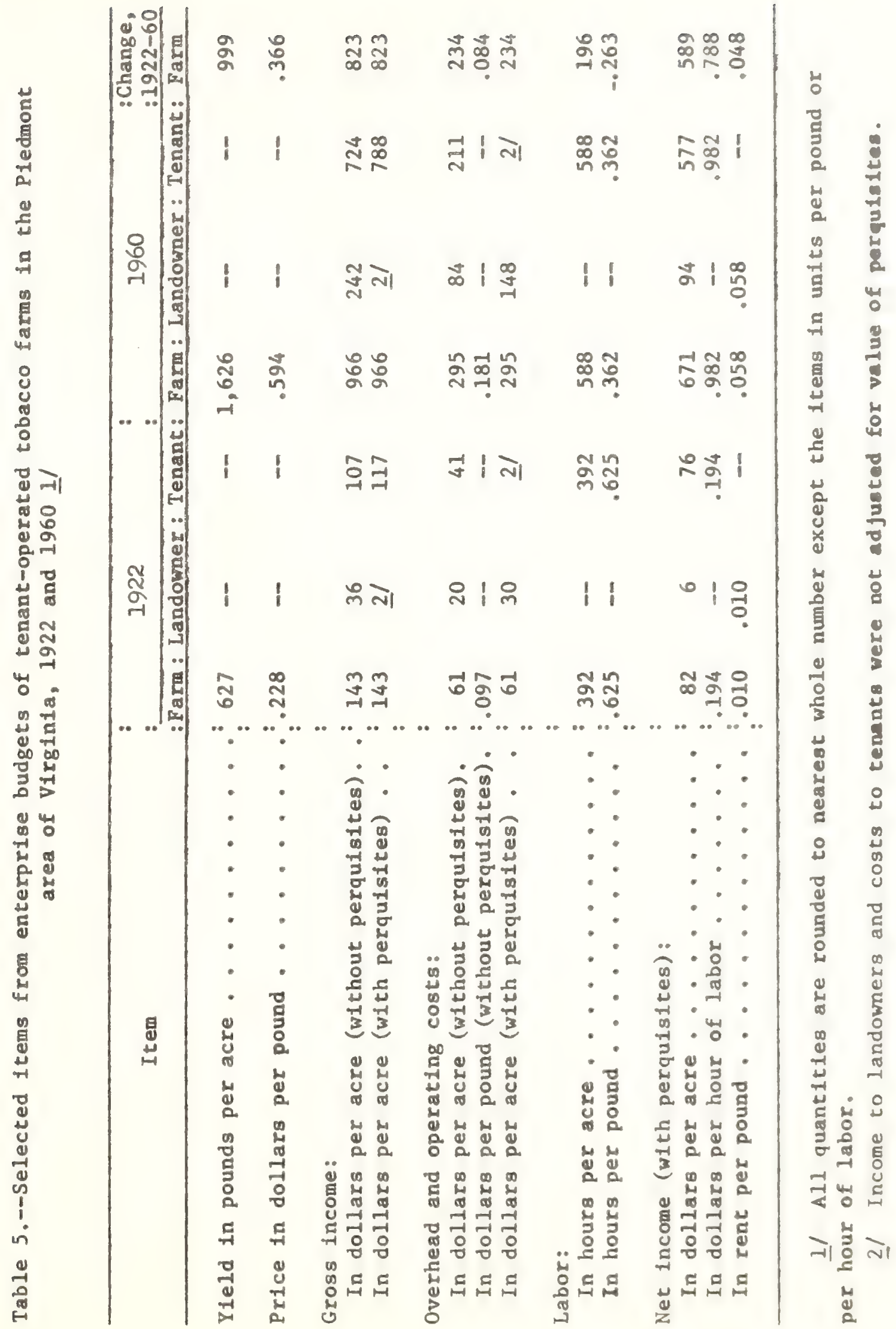


Table 6.--Components of changes in income and costs effecting land rent change from prior to flue-cured tobacco programs to 1960, North Carolina and Virginia

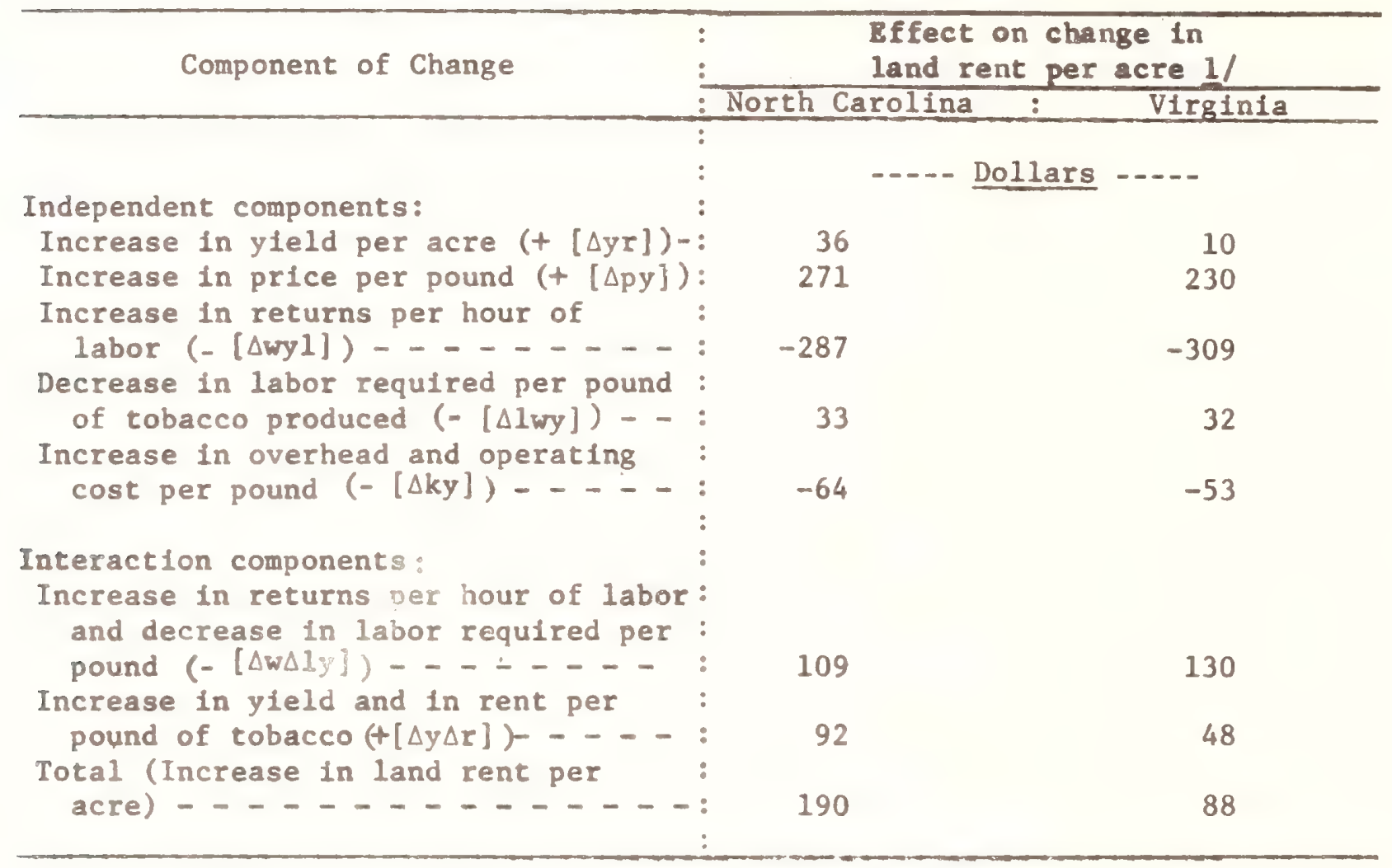

\section{I/ Numbers rounded to nearest dollar.}

overhead and operating costs per pound. Unfortunately, such indirect effects cannot be quantifled. Nor can interaction effects be separated into independent components depicting the contribution of each variable to the interaction.

According to the results and rationale of this study, the magnitude of al1 the components of changes 1 in income and costs affecting land rent is affected ether directly or indirectly by the flue-cured tobacco programs. Altholig th the price of capital items is determined independently of the pro8rems, as 1s the return to labor, the cost of these per pound of tobacco produced is influenced by yields which are affected by the programs.

Increases in yields and prices were the two major effects of the tobacco programs. It is not known how much yield or prices would have increased during the period under study without the programs. However, an analysis of the sensitivity of rent to yield and price changes will provide some information on the relative magnitude of these two effects of the program. 
During 1960-1965, both ylelds per acre and average price per pound of flue-cured tobacco increased about 5 percent. If it 18 assumed that labor required to produce a pound of tobacco, wages, and other costs per pound did not change in the period, the 5-percent increase in yield would increase rent per acre by about $\$ 5$ in Virginia and $\$ 11$ in North Carolina. On the other hand, the 5-percent increase in prices per pound would increase rent per acre by about $\$ 48$ in Virginia and $\$ 55$ in North Caroliaa. 11/ Since, under the assumptions, the only other component of change in rents would be a yleldprice interaction, it appears that rent is much more sensitive to changes in prices of tobacco than to changes in yields.

$11 /$ The implied increases in rent per acre of $\$ 53$ in Virginia and $\$ 66$ in North Carolina during 1960-1965, even if true, do not provide a basis for inferring aggregate increases in rents in the two states. The acreage harvested declined by about 20 percent in the period for each State. Thus, yleld and price increases may have, in effect, actually decreased the acreage which, in turn, increased rent per acre. 
UNITED STATES DEPARTMENT OF AGRICULTURE

WASHINGTON, D.C. 20250
POSTAGE AND FEES PAID U.S. DEPARTMENT OF AGRICULTURE

DFFICIAL BUSINESS 

